\title{
Collagen quantification in rabbit dermal wounds treated with heterologous platelet-rich plasma gel
}

\section{Quantificação de colágenoem feridas dérmicas de coelhos tratados com plasma rico em plaquetas heterólogo gel}

\author{
Maria Elisa Marin Marques ${ }^{1}$; Cecília Braga Laposy²; Mariana Lucas dos Santos \\ Silva ${ }^{3}$; Maria Rosa Santos Breda ${ }^{3}$; Mayara Mascaro Matsumoto ${ }^{3}$; Luis Antonio \\ Justulin Junior ${ }^{4}$; Gisele Alborghetti Nai²; Guilherme Akio Tamura Ozaki ${ }^{5}$; \\ José Carlos Camargo Filho ${ }^{6}$, Rosa Maria Barilli Nogueira ${ }^{2 *}$
}

\begin{abstract}
Platelet-rich plasma (PRP) has been extensively studied as a biomaterial for wound treatment, and the heterologous PRP is usefulin the event that obtaining the patient's own blood is impossible. This study aimed to evaluate and compare wound healing in rabbits and quantify the collagen in experimentally induced wounds in a control group and in a group treated with heterologous PRP gel. We hypothesize that this gelis capable of promoting proper healing with no adverse reactions, increased collagen content. The clinical aspects of coloring, edema, hyperemia, exudation, crust, granulation, pain sensitivity, and retraction index of the wounds were measuredon days 7, 14, and 17 after the injury. Collagen quantification by Picrosirius staining and evaluation under polarized light was performed on the 17th day. Crust was present in both groups at all evaluated time points, with the absence of other clinical signs. The wound contraction rate and collagen quantity did not differ between groups. In conclusion, the suggested hypothesis was partially confirmed; the heterologous PRP gel was unable to increase the amount of collagen and accelerate the wound healing process, however, wound healing was efficient and similar in both groups and there was no local adverse reaction. Thus, despite the scarcity of studies in the literature, the heterologous PRP gel is an effective alternative treatment for wounds in the absence of other sources of PRP.
\end{abstract}

Key words: Wound healing. Rabbits. Collagen. Platelet-rich plasma.

\section{Resumo}

O plasma rico em plaquetas (PRP) tem sido amplamente estudado como um biomaterial para o tratamento de feridas, sendo o produto de fonte heteróloga indicado na impossibilidade de obtenção do sangue do

${ }^{1}$ Discente do Mestrado em Ciência Animal, Universidade do Oeste Paulista, UNOESTE, Presidente Prudente, SP, Brasil. E-mail: melissa@unoeste.br

2 Prof $^{\text {as }} \operatorname{Dr}^{\text {as }}$, Mestrado em Ciência Animal, UNOESTE, Presidente Prudente, SP, Brasil. E-mail: claposy@unoeste.br; patologia@ unoeste.br; rosa@unoeste.br

3 Discentes de Graduação de Medicina Veterinária, UNOESTE, Presidente Prudente, SP, Brasil. E-mail: mari_lucas94@hotmail. com; mariarosa-breda@hotmail.com; matsumoto@hotmail.com

4 Prof. Dr. Assistente, Departamento de Morfologia do Instituto de Biociências, Universidade Estadual Paulista Júlio de Mesquita Filho, UNESP, Botucatu, SP, Brasil. E-mail: justulin@ibb.unesp.br

5 Discente, Departamento de Fisioterapia, Laboratório de Histologia e Histoquímica, Faculdade de Ciências e Tecnologia UNESP, Presidente Prudente, SP, Brasil. E-mail: guiozaki@hotmail.com

${ }^{6}$ Prof. Dr. Assistente, Departamento de Fisioterapia, Faculdade de Ciências e Tecnologia, UNESP, Presidente Prudente, SP, Brasil. E-mail: camargo@ffct.unesp.br

* Author for correspondence 
próprio paciente. O presente estudo teve como objetivo, avaliar e comparar a cicatrização em coelhos, e quantificar o colágeno de feridas experimentalmente induzidas, denominadas controle e tratadas, com PRP heterólogo gel. A hipótese é que este produto seja capaz de promover cicatrização adequada sem reações adversas, e promova aumento do colágeno. Os aspectos clínicos cor, edema, hiperemia, exsudato, crosta, granulação, sensibilidade a dor e índice de retração das feridas foram avaliados nos dias 7, 14 e 17 após a lesão. A quantificação do colágeno, através da coloração com Picrosirius e avaliação sob luz polarizada, foi realizada no $17^{\circ}$ dia. Houve presença de crosta nos dois grupos em todos os momentos avaliados, com ausência dos demais sinais clínicos. O percentual de contração da lesão e quantidade de colágeno não diferiu entre os grupos. Concluiu-se que a hipótese sugerida foi comprovada em partes, ou seja, o PRP heterólogo gel não foi capaz de aumentar a quantidade de colágeno e acelerar o processo de cicatrização tecidual, no entanto, a cicatrização foi eficiente e semelhante entre os dois grupos e não houve nenhum tipo de reação adversa local. Desta forma, apesar da escassez de estudos encontrados na literatura, o PRP heterólogo gel é uma alternativa de tratamento de feridas, na impossibilidade de uso de outras fontes de PRP.

Palavras-chave: Cicatrização de feridas. Coelho. Colágeno. Plasma rico em plaquetas.

\section{Introduction}

Wounds can be caused by various factors and are responsible for causing physical and psychologicalsuffering to individuals, most of the time generating a negative impact on the quality of life of patients and their families, as well as posing a problem for the public health system by increasing government costs (BRASIL, 2002; ALVES; VIEIRA, 2012). Wound treatment strategies are widely discussed in the literature and involve a large number of studies based on various types of substances, especially biomaterials (MELO et al., 2012).

The healing process involves a sequence of cellular and molecular events, as well as different types of cells that interact for reconstitution and wound healing (MANDELBAUM et al., 2003; CAMPOS et al., 2007; REES et al., 2015). According to Naude (2010), the healing process occurs in three phases: inflammation, proliferation, and remodeling. Guo and DiPietro (2010) as well as Ding and Tredget (2015), however, argue that hemostasis may be designated as the initial phase, preceding inflammation.

In the hemostasis phase, vasoconstriction, platelet release reaction, clot formation, and release of proinflammatory cytokines and growth factors prevail(GUO;DIPIETRO, 2010). This is followed by the inflammatory phase, characterized by infiltration of leukocytes, neutrophils, and macrophages, the latter of which are responsible for phagocytosis of microorganisms and wound debridement (DING; TREDGET, 2015). In the proliferative phase, fibroplasia, angiogenesis, granulation tissue formation, and wound contraction by myofibroblasts take place, overlapping the preceding phase (REES et al., 2015). The remodeling phase is the period where vascularization of the wound returns to normal, and then collagen remodeling occurs, an event that can last years, according to Guo and DiPietro (2010).

For the treatment of wounds, it has been discussed that the use of platelet-rich plasma gel (PRP), a platelet concentrate with a high concentration of growth factors (GF) that has been applied in several health fields, may be usedto accelerate the healing process and promote high-quality tissue repair (AKHUNDOV et al., 2012; VENDRUSCULO et al., 2014). Several growth factors have been identified in the PRP, such as the transforming growth factor beta (TGF- $\beta$ ), platelet-derived growth factor (PDGF), vascular endothelial growth factor (VEGF), and epidermal growth factor (EGF) (WOO et al., 2014). During the process of injury repair, the high concentration of these growth factors allows for an increase of angiogenesis, stimulation of proliferation, migration, and cellular differentiation, as well as boosting collagen production (PAL et al., 
2012; SCLAFANI; AZZI, 2015). During the healing process, collagen deposition is a clinically important factor for defining the scar quality. Collagen is the main component of the dermal matrix and plays a structural role thanks to its mechanical properties that give shape and structure to tissues (RICARDBLUM, 2011).

The heterologous PRP has been proposed as an important and safe alternative in cases where the patient has unfeasible or contraindicated conditions for obtaining their own blood (SHAN et al., 2013; SUZUKI et al., 2013; MARCK et al., 2014). In studies in our laboratory, Abegão et al. (2015) reported that the heterologous PRP gel was able to promote wound healing without causing harmful effects. However, there is a need for further studies to evaluate the quality of scar tissue in wounds treated with heterologous PRP as well as to quantify the presence of collagen. Therefore, we sought to evaluate and compare healing in rabbits and quantify the collagen in experimentally induced wounds between a control group and a group treated with heterologous PRP gel. We hypothesize that the heterologous PRP gel is able to promote proper healing, does not induce any adverse reactions, promotes increased collagen in tissues, and accelerates healing.

\section{Materials and Methods}

The Ethics Committee on Animal Use (CEUA) approved this study under protocol number 2362 of the university of origin.

\section{Macroscopic and morphometric analysis}

On days 7 (M7), 14 (M14), and 17 (M17) after experimental induction of dermal wounds in the dorsal cervical region on six rabbits, called A-side control group (treated with $0,5 \mathrm{~mL}$ of $0.9 \%$ sodium chloride) and B-side treated group (using 0,5 $\mathrm{mL}$ of PRP heterologous gel obtained by double centrifugation from dogs), as previously reported by Abegão et al. (2015), we clinically assessed the wound color (1- pinkish, 2- yellowish, 3- pale, 4- cyanotic), exudate, crust, edema, hyperemia, and granulation tissue (1- missing, 2- present). Morphometric analysis was carried out using graph digital caliper (DC-60 Western ${ }^{\circledR}$ ) to measure the major and minor diameters of the wound. The area was then calculated using the following mathematical equation described by Prata et al. (1988): $A=\pi \times R$ $\times \mathrm{r}$, where $\mathrm{A}=$ area of the wound, $\mathrm{R}=$ larger radius, and $r=$ smaller radius. The calculation of the wound contraction rate was expressed by the formula used by Ribeiro et al. (2009): Af-Ai/Ai × 100, where Ai $=$ initial wound area $(\mathrm{M} 0)$ and $\mathrm{Af}=$ final wound area (M17).

Samples, processing, and collagen quantification using image analysis

Twelve 8-mm punch biopsy skin samples were obtained by Abegão et al. (2015) in the $17^{\text {th }}$ day of the healing process, fixed in $10 \%$ buffered formalin solution for 24 hours, and then embedded in paraffin. In this study, serial tissue sections, 5 - $\mu \mathrm{m}$ thick were prepared with a manual microtome paraffin blocks and then stained for $30 \mathrm{~min}$ using Picrosiriusred F3BA were sectioned for evaluation of interstitial collagen fraction (LATTOUF et al., 2014). Sections were then mounted for observation under polarized light microscopy

Histological analysis was performed by the same pathologist without prior knowledge of the sample identification. To capture the images, a light microscope (Leica DMLB, Wetzlar, Hessen, Germany) was used, with and without polarization, coupled to a camera (Leica DFC300 FX, Wetzlar, Hessen, Germany). The images seen in the microscope were projected on a monitor using an image analyzer software (Leica QWin Plus, Wetzlar, Hessen, Germany). They were then randomly selected three fields, including the compartments of the epidermis, superficial (papillary layer) and deep dermis (reticular layer), the view under a 
standardized 20X objective lens. The collagen fibers in each field have been identified by the image analyzer, which determined the percentage of the total area occupied by them. The percentage of collagen was determined by averaging the three fields evaluated.

\section{Statistical analysis}

To assess whether there was a difference in the size of the wound areas between the time points, as well as between the control (A) and treated group (B), the Kolmogorov-Smirnov test was used to assess the normality of the data, and subsequently the nonparametric Kruskal-Wallis test was used to test for equality of variances. The same tests were used to determine the difference of collagen concentration present in the wounds of the groups (A) and (B), the results of which were expressed as a percentage. The Action Stat software (Estatcamp, São Carlos, São Paulo, Brazil) was usedfor all statistical analysis and a significance level of $5 \%$ $(p<0.05)$ was used.

\section{Results and Discussion}

This study used the heterologous PRP gel for cutaneous wound healing which, according to Barrionuevo et al. (2015), proves to be as effective as autologous and homologous sources. In studies in the fields of dentistry (PAL et al., 2012; FORNI et al., 2013), orthopedics (FERNÁNDEZ-SARMIENTO et al., 2013; ZHANG et al., 2013), vascular surgery (LAWLOR et al., 2011), and dermatology (BERNUZZI et al., 2010; DEMIDOVA-RICE et al., 2012), PRP from different sources has been efficient and inexpensive (REZENDE et al., 2011; BARRIONUEVO et al., 2015).
The absence of granulation tissue, exudate, pain, edema, and hyperemia at all times observed from M7 agrees with the reports of Ribeiro et al. (2009), Abegão et al. (2015), and Barrionuevo et al. (2015), which mention the presence of these signals only until the peak of the inflammatory phase, i.e., three days after the injury.

Unlike the aforementioned authors, Bernuzzi et al. (2010) and Ostvar et al. (2015) treated wounds with autologous PRP and they observed tissue hypergranulation. According to Engelen et al. (2004), some factors may promote the formation of granulation tissue, such as high body mass, lesions on the lower limbs, mobility of the region, infections and trauma.

The morphological analysis showed the presence of dry crust in $16.6 \%$ of all wounds at M7. The amount of crusted wounds increased to $66.6 \%$ in the control group and $83.3 \%$ in the treated group at $\mathrm{M} 14$, and then decreased to $50 \%$ in the control group and $33.3 \%$ in the treated group at M17. Other authors, who treated wounds with other products, reported a significant increase in the formation of crusts from the $7^{\text {th }}$ day (COSTA et al., 2014).

In this study, no statistically significant difference $(p>0.05)$ was found in relation to the wound contraction rate of the group treated with heterologous PRP gel when compared to the control group (Figure 1). On comparing time points, only M17 differed ( $>>0.05$ ) from M0 (Figure 2). Kane et al. (2015), who used an autologous PRP source after ankle prosthesis implantation, have also reported a lack of a difference between control and treated groups in promoting accelerated healing. In contrast to these results, the study of Ostvar et al. (2015) showed that wounds treated with autologous PRP had a significantly faster healing when compared to the control. 
Figure 1. Evaluation of the wound contraction rate in the different animals of the control and treated group.

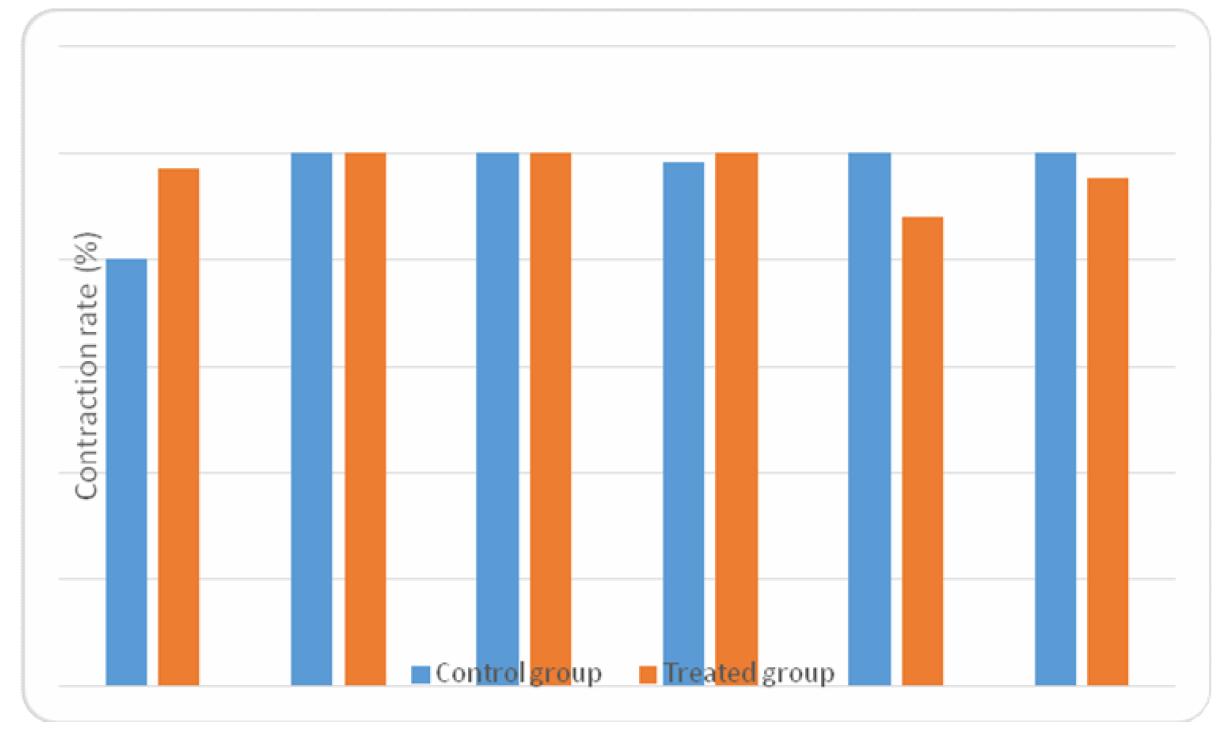

Figure 2. Changes in wound area at all time points evaluated for animals of the control and treated group.

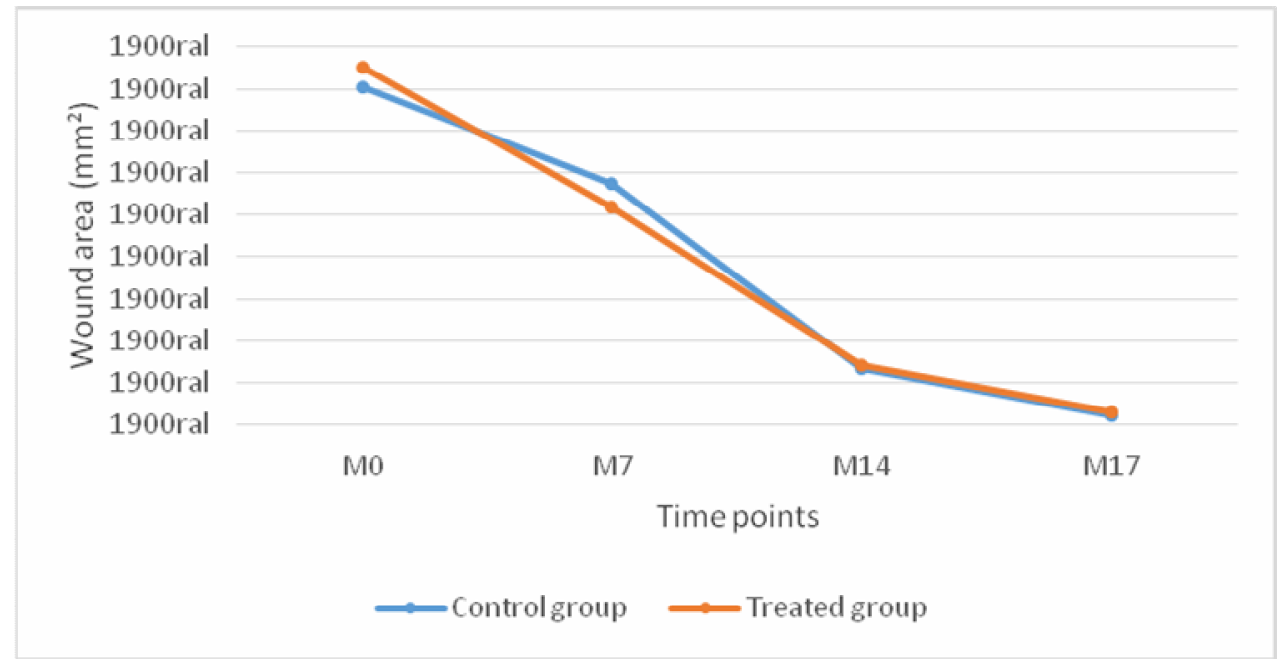

Using polarized light microscopy, we observed that the collagen fibers stained with Picrosirius form a dense network characterized by the birefringent property of the collagen molecule, represented in this study by Figures $3 \mathrm{G}$ and $3 \mathrm{H}$ (VALENTI et al., 2010). Other methods that allow the observation of collagen fibers are found in the literature, such as Masson'sTrichrome staining and Hematoxylin and Eosin staining (DEROSSI et al., 2009; ABEGÃO et al., 2015); however the staining solution used in this study is considered more specific for the evaluation of collagen (LATTOUF et al., 2014). The results obtained from the quantification of collagen are shown in Figure 4. Comparing the percentage of collagen present in the wounds of the control and treated group, we conclude that there is no statistically significant difference $(p>0.05)$ between the groups, and therefore, the heterologous PRP gel did not affect the amount of collagen. This result corroborates Abegão et al. (2015) who, while using a less accurate technique, also observed no increase in collagen by using heterologous PRP gel for wound healing in rabbits. 
Figure 3. Appearance of the wounds on the $17^{\text {th }}$ day. On the right are images of the untreated wound, and on the left are images of the wound treated with heterologous PRP gel. Macroscopic images of the wounds: A and B,complete healing of both wounds. Light microscopy of the wounds (Hematoxylin-Eosin, 400X magnification): C,discrete neovascularization (note congested capillaries - thin arrows) and moderate amount of fibroblasts; D, discrete neovascularization (note congested capillaries - thin arrows), mild inflammatory infiltrate (asterisks), and large amount of fibroblasts. Picrosirius staining (200X magnification): E and F, visible collagen fibers in red. Evaluation of Picrosirius staining by using polarized light (200X magnification): $\mathrm{G}$ and $\mathrm{H}$,visible birefringence of collagen fibers in red.

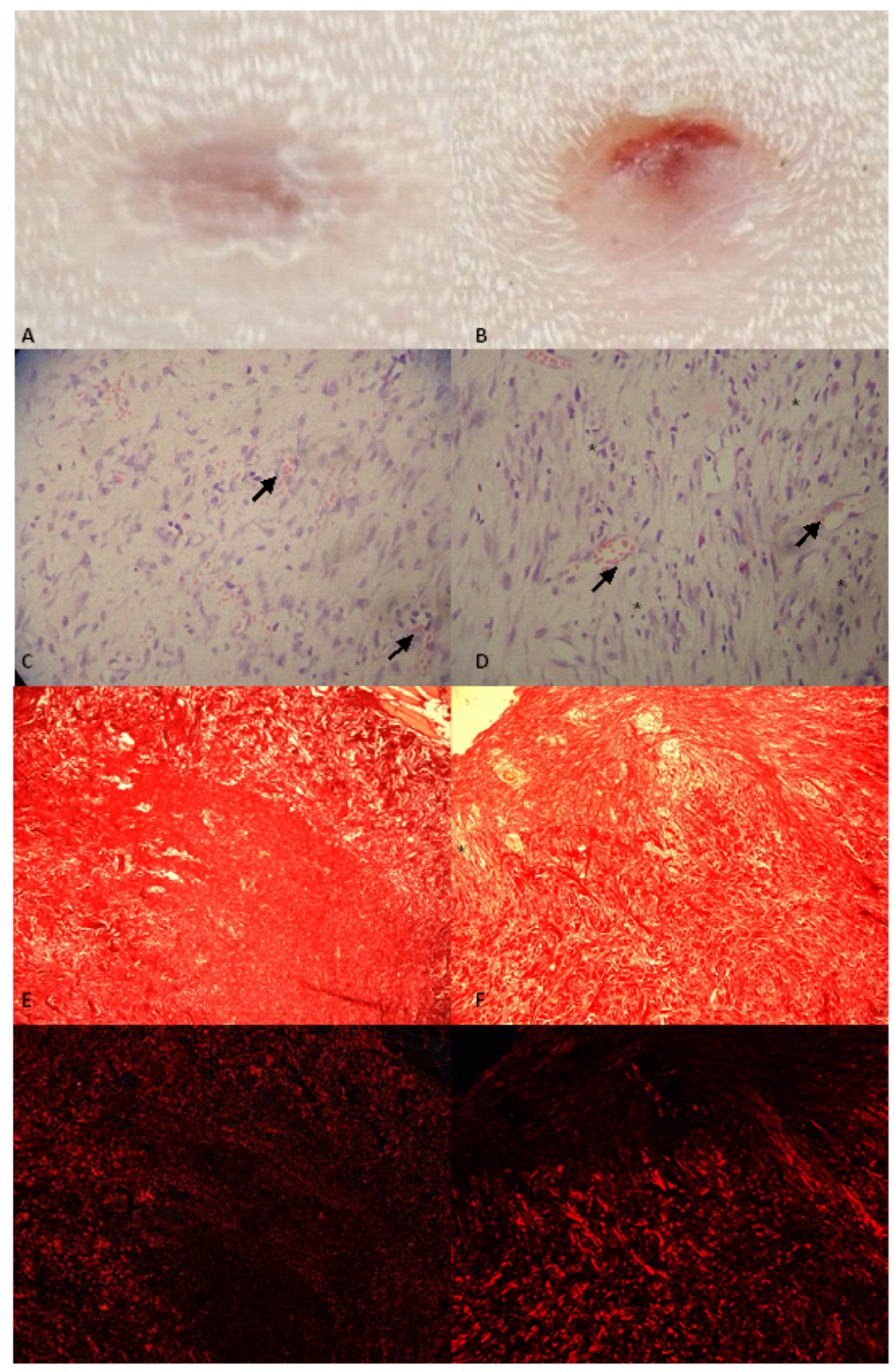


Picrosirius has been used for more than 30 years to identify the types of collagen using polarized light, where the thick fiber bundles of type I collagen presents a high birefringence using polarized light, represented by yellow, orange, and red staining. The thin fibrils of type III collagen presents a low birefringence, represented by green staining (JUNQUEIRA et al., 1979; CAMPOS et al., 2007; COEN et al., 2013; CAVALLO et al.,
2014; NICOLAU et al., 2014). In contrast, other authors report that the colors of the polarization are dependent only on the three-dimensional organization of the molecule and the thickness of the fibers, and not on the composition of specific types of collagen present in the fibers, which would be better analyzed using immunohistochemistry techniques (PIERARD, 1989; BORGES et al., 2007, COLEMAN, 2011; LATTOUF et al., 2014).

Figure 4. Percentage of collagen in the wounds of the control group and in wounds treated with heterologous PRP gel, after Picrosirius staining and observation using polarized light microscopy.

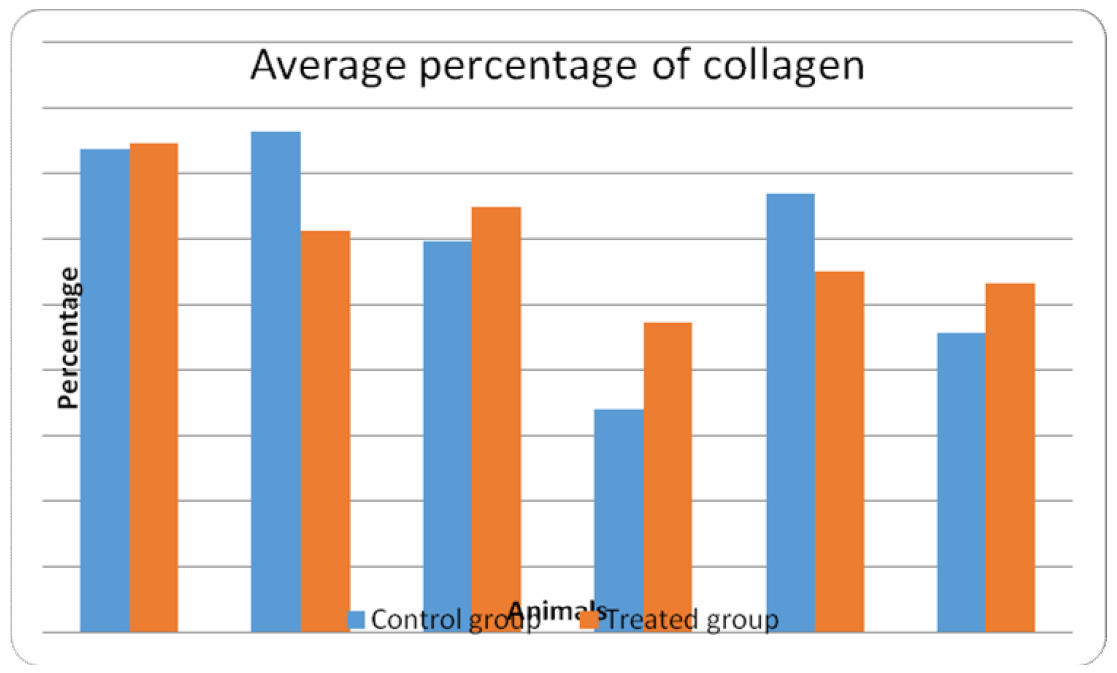

However, according to studies carried increase the amount of collagen and accelerate the out by Borges et al. (2007) and Lattouf et al. (2014), Picrosirius staining to analyze collagen quantification, deposition, and organization in normal and pathological tissues remains the preferred method.

During this work, we found that autologous PRP is widely studied in several fields of health; however,studies with heterologous PRP are lacking. Thus,more studies need to be carried out on the use of heterologous PRP.

In conclusion, the hypothesis was partially confirmed; wound healing was efficient and similar in both groups and there was no local adverse reaction, although the heterologous PRP gel was not able to wound healing process. Thus, despite the scarcity of studies in the literature, the heterologous PRP gel may be an alternative treatment for wounds in the absence of other sources of PRP.

\section{Acknowlegments}

To Oeste Paulista University for financial support and the available animals; to the Extracellular Matrix Laboratory, Department of Morphology - Biosciences Institute of BotucatuUNESP (Universidade Estadual Paulista) and to the Histology and Histochemistry Laboratory, Department of Physiotherapy - FCT / UNESP. 


\section{References}

ABEGÃO, K. G. B.; BRACALE, B. N.; DELFIM, I. G.; SANTOS, E. S.; LAPOSY, C. B.; NAI, G. A.; GIUFFRIDA, R.; NOGUEIRA, R. M. B. Effects of heterologous platelet-rich plasma gel on standardized dermal wound healing in rabbits. Acta Cirúrgica Brasileira, São Paulo, v. 30, n. 3, p. 209-215, 2015.

AKHUNDOV, K.; PIETRAMAGGIORI, G.; WASELLE, L.; DARWICHE, S.; GUERID, S.; SCALETTA, C.; HIRT-BURRI, N.; APPLEGATE, L. A.; RAFFOUL, W. V. Development of a cost-effective method for plateletrich plasma (PRP) preparation for a topical wound healing. Annais of Burns and Fire Disasters, Palermo, v. 25, n. 4, p. 207-213, 2012.

ALVES, P.; VIEIRA, M. Ensino em feridas: formação pré-graduada em enfermagem. Journal of Tissue Regeneration and Healing, Porto, v. 1, n. 1, p. 4-9, 2012.

BARRIONUEVO, D. V.; LAPOSY, C. B.; ABEGÃO, K. G.; NOGUEIRA, R. M.; NAI, G. A.; BRACALE, B. N.; DELFIM, I. G. Comparison of experimentallyinduced wounds in rabbits treated with different sources of platelet-rich plasma. Laboratory Animals, Londres, v. 49, n. 3, p. 209-214, 2015.

BERNUZZI, G.; TARDITO, S.; BUSSOLATI, O.; ADORNI, D.; CANTARELLI, S.; FAGNONI, F.; ROSSETTI, A.; AZZARONE, M.; FICARELLI, E.; CALEFFI, E.; GAZZOLA, G.; FRANCHINI, M. Platelet gel in the treatment of cutaneous ulcers: the experience of the immunohaematology and transfusion centre of parma. Blood Transfusion, Milão, v. 8, n. 1, p. 237-247, 2010.

BORGES, L. F.; GUTIERREZ, P. S.; MARANA, H. R. C.; TABOGA, S. R. Picrosirius-polarization staining method as an efficient histopathological tool for collagenolysis detection in vesical prolapse lesions. Micron, Oxford, v. 38, n. 1, p. 580-583, 2007.

BRASIL. Ministério da Saúde. Atenção Básica. Manual de condutas para úlceras neurotróficas e traumáticas. Secretaria de Políticas de Saúde. Brasília: Editora MS, 2002. 56 p.

CAMPOS, A. C. L.; BORGES-BRANCO, A.; GROTH, A. K. Wound healing. Arquivos Brasileiros de Cirurgia Digestiva, São Paulo, v. 20, n. 1, p. 51-58, 2007.

CAVALlO, J. A.; ROMA, A. A.; JASIELEC, M. S.; OUSLEY, J.; CREAMER, J.; PICHERT, M. D.; BAALMAN, S.; FRISELLA, M. M. Remodeling characteristics and collagen distribution in synthetic mesh materials explanted from human subjects after abdominal wall reconstruction: an analysis of remodeling characteristics by patient risk factors and surgical site classifications. Surgical Endoscopy, Berlim, v. 28, n. 6, p. 1852-1865, 2014.

COEN, M.; MENEGATTI, E.; SALVI, F.; MASCOLI, F.; ZAMBONI, P.; GABBIANI, G.; BOCHATONPIALLAT, M. L. Altered collagen expression in jugular veins in multiple sclerosis. Cardiovascular Pathology, Nova Iorque, v. 22, n. 1, p. 33-38, 2013.

COLEMAN, R. Picrosirius red staining revisited. Acta Histochemica, Jena, v. 113, n. 1, p. 231-233, 2011.

COSTA, F. L. S.; TIUSSI, L. D.; NASCIMENTO, M. S.; CORREA, A. C. S.; YASOJIMA, E. Y.; PIRES, A. A. P. Diclofenac topical gel in excisional wounds maintain heal quality and reduce phlogistic signals. Acta Cirúrgica Brasileira, São Paulo, v. 29, n. 5, p. 328-333, 2014.

DEMIDOVA-RICE, T. N.; WOLF, L.; DECKENBACK, J.; HAMBLIN, M. R.; HERMAN, I. M. Human plateletrich plasma and extracellular matrix-derived peptides promote impaired cutaneous wound healing in vivo. Plos One, São Francisco, v. 7, n. 2, p. 1-10, 2012.

DEROSSI, R.; COELHO, A. C. A. O.; MELLO, G. S.; FRAZÍLIO, F. O.; LEAL, C. R. B.; FACCO, G. G.; BRUM, K. B. Effects of platelet-rich plasma gel on skin healing in surgical wound in horses. Acta Cirúrgica Brasileira, São Paulo, v. 24, n. 4, p. 276-281, 2009.

DING; J.; TREDGET, E. E. The role of chemokines in fibrotic wound healing. Advances in Wound Care, New Rochelle, v. 4, n. 11, p. 673-686, 2015.

ENGELEN, M.; BESCHE, B.; LEFAY, M. P.; HARE, J.; VLAMINK, K. Effects of ketanserin on hypergranulation tissue formation, infection, and healing of equine lower limb wounds. The Canadian Veterinary Journal, Guelph, v. 45, n. 1, p. 144-149, 2004.

FERNÁNDEZ-SARMIENTO, J. A.; DOMÍNGUEZ, J. M.; GRANADOS, M. M.; MORGAZ, J.; NAVARRETE, R.; CARRILLO, J. M.; GÓMEZ-VILLAMANDOS, R. J.; MUÑOZ-RASCÓN, P.; de las MULAS, J. M.; MILLÁN, Y.; GARCÍA-BALLETBÓ, M.; CUGAT, R. Histological study of the influence of plasma rich in growth factors (PRGF) on the healing of divided achilles tendons in sheep. The Journal of Bone and Joint Surgery, Boston, v. 95, n. 3, p. 246-255, 2013.

FORNI, F.; MARZAGALLI, M.; TESEI, P.; GRASSI, A. Platelet gel: applications in dental regenerative surgery. Blood Transfusion, Milão, v. 11, n. 1, p. 102-107, 2013.

GUO, S.; DIPIETRO, L. A. Factors affecting wound healing. Journal of Dental Research, Chicago, v. 89, n. 3, p. 219-229, 2010. 
JUNQUEIRA, L. C. U.; BIGNOLAS, G.; BRENTANI, R. R. Picrosirius staining plus polarization microscopy, a specific method for collagen detection in tissue sections. Histochemical Journal, Londres, v. 11, n. 1, p. 447-455, 1979.

KANE, J. M.; COSTANZO, J. A.; RAIKIN, S. M. The efficacy of platelet-rich plasma for incisional healing after total ankle replacement using the agility total ankle replacement system. Foot and Ankle International, Baltimore, v. 1, n. 1, p. 1-6, 2015.

LATTOUF, R.; YOUNES, R.; LUTOMSKI, D.; NAAMAN, N.; GODEAU, G.; SENNI, K.; CHANGOTADE, S. Picrosirius red staining a useful tool to appraise collagen networks in normal and pathological tissues. Journal of Histochemistry and Cytochemistry, Baltimore, v. 62, n. 10, p. 751-758, 2014.

LAWLOR, D. K.; DeROSE, G.; HARRIS, K. A.; LOVELL, M. B.; NOVICK, T. V.; FORBES, T. L. The role of platelet-rich plasma in inguinal wound healing in vascular surgery patients. Vascular and Endovascular Surgery, Glen Head, v. 45, n. 3, p. 241-245, 2011.

MANDELBAUM, S. H.; DI SANTIS, E. P.; MANDELBAUM, M. H. S. Cicatrization: current concept and auxiliary resources - Part 1. Anais Brasileiros de Dermatologia, Rio de Janeiro, v. 78, n. 4, p. 393-410, 2003.

MARCK, R. E.; MIDDELKOOP, E.; BREEDDERVELD, R. S. Considerations on the use of platelet-rich plasma, specifically for burn treatment. Journal of Burn Care and Research, Hagerstown, v. 35, n. 3, p. 219-227, 2014.

MELO, F.; ROSA, P.; SOUSA, S. Aoxigeno terapia hiperbárica e a pessoa com ferida por queimadura térmica. Journal of Tissue Regeneration and Healing, Porto, v. 1, n. 1, p. 19-24, 2012.

NAUDE, L. The practice and science of wound healing: history and physiology of wound healing. Professional Nursing Today, Littelton Manor, v. 14, n. 3, p. 17-21, 2010.

NICOLAU, J. A. Z.; FARIA, P. F.; MARQUES, L. O.; HOEPERS, D. F.; ROCHA, A. D.; SOBRAL, A. C. L. Analysis of the effect of topical o estradiol and progesterone in wound healing in rats. Surgical and Cosmetic Dermatology, Rio de Janeiro, v. 6, n. 2, p. 126129, 2014.

OSTVAR, O.; SHADVAR, S.; YAHAGHI, E.; AZMA, K.; FAYYAZ, A. F.; AHMADI, K. Effect of platelet-rich plasma on the healing of cutaneous defects exposed to acute to chronic wounds: a clinic-histopathologic study in rabbits. Diagnostic Pathology, Londres, v. 10, n. 85, p. 1-6, 2015.
PAL, U. S.; MOHAMMAD, S.; SINGH, R. K.; DAS, S.; SINGH, N.; SINGH, M. Platelet rich growth factor in oral and maxillofacial surgery. National Journal of Maxillofacial Surgery, Lucknow, v. 3, n. 2, p. 118-123, 2012.

PIERARD, G. E. Sirius red polarization method is useful to visualize the organization of connective tissues but not the molecular composition of their fibrous polymers. Matrix, Stuttgart, v. 9, n. 1, p. 68-71, 1989.

PRATA, M. B.; HADDAD, C. M.; GOLDENBERG, S.; SIMÕES, M. J.; MOURA, L. A.; TRABULSI, L. R. Uso tópico do açúcar em ferida cutânea. Estudo experimental em rato. Acta Cirúrgica Brasileira, São Paulo, v. 3, n. 2, p. 43-48, 1988.

REES, P. A.; GREAVES, N. S.; BAGUNEID, M.; BAYAT, A. Chemokines in wound healing and as potencial therapeutic targets for reducing cutaneous scarring. Advances in Wound Care, New Rochelle, v. 4, n. 11, p. 687-703, 2015.

REZENDE, M. U.; SILVA, R. B. B.; BASSIT, A. C. F.; TATSUI, N. H.; SADIGURSKY, D.; BOLLIGER NETO, R. Effect of platelet-rich plasma on impact-induced chondrocyte apoptosis. Acta Ortopédica Brasileira, São Paulo, v. 19, n. 2, p. 102-105, 2011.

RIBEIRO, G.; MARTINS, C. B.; SILVA, M. A. G.; BORGES, V. P.; LACERDA NETO, J. C. Uso tópico de ketanserina na cicatrização de feridas cutâneas induzidas em equinos. Arquivos Brasileiros de Medicina Veterinária e Zootecnia, Belo Horizonte, v. 61, n. 1, p. 144-148, 2009.

RICARD-BLUM, S. The collagen family. Cold Spring Harbor Perspectives in Biology, Woodbury, v. 3, n. 1, p. 1-19, 2011.

SCLAFANI, A. P.; AZZI, J. Platelet preparations for use in facial rejuvenation and wound healing: a critical review of current literature. Aesthetic Plastic Surgery, New York, v. 39, n. 1, p. 495-505, 2015.

SHAN, G. Q.; ZHANG, Y. N.; MA, J.; LI, Y. H.; ZUO, D. M.; QIU, J. I.; CHENG, B.; CHEN, Z. L. Evaluation of the effects of homologous platelet gel on healing lower extremity wounds in patients with diabetes. The International Journal of Lower Extremity Wounds, Thousand Oaks, v. 12, n. 1, p. 22-29, 2013.

SUZUKI, S.; MARIMOTO, N.; IKADA, Y. Gelatin gel as a carrier of platelet-derived growth factors. Journal of Biomaterials Applications, Lancaster, v. 28, n. 4, p. 595-606, 2013. 
VALENTI, D. M. Z.; SILVA, J. A.; TEODORO, W. R.; VELOSA, P. A.; MELLO, S. B. V. Effect of clay application on the Histoarchitecture of rats collagen skin. Revista Brasileira de Ciências da Saúde, Paraíba, v. 8, n. 23, p. 22-31, 2010.

VENDRUSCULO, C. P.; ALVES, A. L. G.; BROSSI, P. M.; BACCARIN, R. Y. A. Autologous conditioned serum and platelet-rich plasma in equine orthopedic therapeutics. Semina: Ciências Agrárias, Londrina, v. 35, n. 5, p. 2607-2624. 2014.
WOO, S. H.; JEONG, H. S.; KIM, J. P.; KOH, E. H.; LEE, S. U.; JIN, S. M.; KIM, D. H.; SOHN, J. H.; LEE, S. H. Favorable vocal fold wound healing induced by platelet-rich plasma injection. Clinical and Experimental Otorhinolaryngology, Seoul, v. 7, n. 1, p. 47-52, 2014.

ZHANG, J.; MIDDLETON, K. K.; FU, F. H.; IM, H.; WANG, J. H. HGF mediates the anti-inflammatory effects of PRP on injured tendons. Plos One, São Francisco, v. 8, n. 6 , p. 1-12, 2013. 